\title{
Housing and communal services as a driver of the Urals Federal District sustainable development
}

\author{
Irina Belova ${ }^{1, *}$ \\ ${ }^{1}$ Chelyabinsk State University, 129, Br.Kashirinyh Str., 454001, Chelyabinsk, Russia
}

\begin{abstract}
The study aims to analyze the current state of the housing and communal services market in the Ural Federal District. The features of the housing and communal services market in the Urals Federal District have been investigated, key trends in the development of the studied market have been identified. The assessment of the volume of the housing and communal services market in the Urals Federal District in value terms is carried out, its dynamics in 2015-2020 is presented. The nature of the investigated market volume dynamics is revealed, the average annual rate of its growth and the drivers of market growth are determined. The structure of housing and communal services and the structure of the housing stock in the Ural Federal District within the regions and districts are considered. The heterogeneity of these structures is shown. A significant share (about 66.0\%) in both structures presented falls on Sverdlovsk and Chelyabinsk regions. The study is based on statistical data from the Federal State Statistics Service of the Russian Federation, data from specialized portals (Unified information resource - GIS Housing and Communal Services, State Corporation - Fund for Assistance to Reforming Housing and Utilities Sector (Housing and Utilities Fund)). The results obtained in this work helps further research to conduct a competitive analysis on the housing and communal services market in the Urals Federal District, determine the shares of the largest competitors in the studied market, estimate the volume of housing and communal services consumption per capita, as well as the saturation and estimated potential of the housing and communal services market in the Urals Federal District.
\end{abstract}

\section{Introduction}

The development of housing and communal services is one of the leading systemic indicators of sustainable development of the city, region, and state. The economic efficiency of the housing and communal sector is very significant; however, its indirect impact on the efficiency of social reproduction of capital is even more significant due to its influence and determination of the population's level and quality of life. In turn, the specifics of the functioning of the modern housing and communal services system necessitates the identification and systematization of features, trends, which makes it

*Corresponding author: belova@csu.ru 
possible to manage many factors of its development. Simultaneously, given the significant nature of the housing and communal services industry, its features, and collective focus, the market saturation and demand in this niche are unrealizable. The market has a high potential capacity. However, market potential and its qualitative development are constrained by institutional, socio-economic, organizational, legal, and technological factors.

The study aims to analyze the current state of the housing and communal services market within the Ural Federal District (UrFO).

The role of the housing and communal services sector in the structure of the regional economy is due to the qualitative content of this sector's properties, its influence on the stability of cities and regions. The study of the impact of housing and communal services on the city sustainability, the study of the leading indicators and components of the city stability ensuring associated with the improvement and modernization of housing and communal services was carried out by Shalbolova and et.al [10]. Taranukha and Zhuldybina [13] proposed a methodology for assessing an enterprise's sustainable development using an integral indicator reflecting the level of performance in different periods of management of enterprises in the sphere of communal housing services. The dynamics of the main indicators characterizing the conditions and results of human development in the regions included in the Ural Federal District of Russia, including labor productivity, was disclosed by Barhatov [1]. Kemaykin and Pavlenkov [4] studied modern trends in developing housing and communal services in Russia. Lvova and colleagues proposed a cardinal direction for developing the housing and communal services sector - a decrease in private business presence in the industry [5]. They proposed abandoning big business and total state control of natural monopolies in the energy sector, housing, and communal services and transport. The functioning of private business in the context of small and medium-sized enterprises, including companies providing housing management services, is influenced by many internal and external factors, which were investigated by Nikolaeva and Pletnev [7], Barhatov and Belova [2]. The aspect of trust to the Russian economy and business environment were studied by Benz and colleagues [3]. A methodology for a comprehensive assessment of the greening level of housing and communal services in the context of sustainable development of Ukraine regions was proposed by Shtogryn and colleagues [11]. Features of housing and communal services' functioning and the main directions of reforming housing and communal services were investigated by Nenakhova [6], Plotnikova and Sorokina [9]. Yu. Sokolov [12] revealed issues related to the systemic crisis of the housing and communal services in Russia, reforming the housing and communal services, the state of the fixed assets of the housing and communal services. The state information system of housing and communal services as the basis for managing network relations in Russia was studied by Dyachenko and colleagues [8].2 Materials and methods

The theoretical and methodological basis for this study was analytical and reviewed articles in studying the problems of the functioning of housing and communal services in Russia in general and in the Ural Federal District in particular. The range of coverage of these problems is comprehensive, and the qualitative development of the housing and communal services market is constrained by the low level of real incomes of the population, high wear and tear of communal infrastructure, insufficient investment in the industry, low efficiency of management companies and subcontractors, the absence of the institution of homeowners, a poorly formed culture of consumption and payment for housing. - utilities, a large volume of arrears on payments for housing and communal services, a low level of digitalization in the industry.

General scientific methods, including comparative and graphical analysis, induction, deduction, synthesis, systems approach, economic and mathematical research methods, 
were used as the methodological tools of this research.

The information base of this study was the data of the Federal State Statistics Service of the Russian Federation, namely, data from the Unified Interdepartmental Information and Statistical System (EMISS), data from specialized portals, including the Unified Information Resource - GIS Housing and Communal Services, the State Corporation - Fund for Assistance to Reforming Housing and Utilities Sector (Housing and Utilities Fund ).

\section{Results}

\subsection{Features of the housing and communal services market in the Urals Federal District}

The following features characterize the housing and communal services market in the Ural Federal District:

- There is no adequately formed institution of active and responsible owners of premises in apartment buildings with certain rights, effective mechanisms for the implementation of these rights, as well as the necessary level of responsibility.

Reforming the sphere of housing and communal services in the Russian Federation in general and in the Ural Federal District, in particular, is carried out within the framework of such areas as housing construction and housing and public services. At the same time, the main tasks of the reform include: creating safe and favorable living conditions for citizens; creation of adequate tools for housing stock management; reduction of unsuitable housing stock; providing financial support to the constituent entities of the Russian Federation and municipalities for the implementation of capital repairs of houses; reducing the costs of enterprises providing housing and communal services and tariffs for housing and communal services, provided that the quality of the services provided is maintained, etc.

- One of the main problems in the housing and communal services sector is the high and growing physical and moral deterioration of the communal infrastructure. According to the inventory of all utility networks, conducted by the Ministry of Construction of the Russian Federation in February 2020, the wear of networks across the country averages $58.0 \%$ with a total length of over $900,000 \mathrm{~km}$. Simultaneously, the deterioration of heating and electric networks in the regions of the Ural Federal District reaches $60.0 \%$, and of water supply and sewerage networks - 68.0-70.0\%. Only $4.0-5.0 \%$ change annually, which is an insufficient volume of work on replacing dilapidated networks and reconstructing communal facilities. This ultimately leads to increased wear and tear.

The cost of housing and communal services in the Ural Federal District varies depending on the regions and occupies a different share in households' monthly expenses. According to a study by Sberbank - SberData, utility bills account for $11.4 \%$ of monthly household expenditures on average across the country, but this figure varies significantly from region to region. So, in the Yamalo-Nenets Autonomous Okrug the share of housing and communal services in the monthly expenses of households was $12.76 \%$, in the KhantyMansiysk Autonomous Okrug - 11.23\%, in the Kurgan region - 11.64\%, in the Sverdlovsk region $-10.77 \%$, in the Chelyabinsk region $-9.44 \%$. The highest share of such costs among the Urals Federal District regions was established in the Tyumen region $-13.87 \%$.

- Payment for utilities by consumers can be carried out under "direct contracts" from resource supplying organizations (RSO) or under contracts with the MC / HOA. However, the tariff for consumers in one RSO's territory should be the same for both consumers receiving utilities from the RSO and for consumers receiving utilities from the MC / HOA. At the same time, it is essential to note that the Russian Federation's current legislation provides for the possibility of switching to a "direct contract" by the decision of the owners 
of premises. For each apartment building, individual decisions are made to switch to "direct contracts, " making it difficult to account for additional costs in tariffs. Besides, the transition to "direct contracts" entails additional RNO expenses for calculating the cost of utilities, recalculations, maintaining personal accounts, producing and delivering receipts to consumers, handling claims, filing claims, participating in court hearings, etc.

- The concentration of operating companies providing housing management services within each region in the Ural Federal District is as follows. According to the author's calculations, about $45.9 \%$ of such companies are concentrated in the Sverdlovsk Region. The Chelyabinsk Region accounts for another $21.9 \%, 11.0 \%$ of such companies are concentrated in the Kurgan region. $10.4 \%$ - in the Tyumen region, and the remaining $6.9 \%$ and $3.9 \%$ of the companies are concentrated in the Khanty-Mansi and Yamalo-Nenets autonomous districts, respectively. It is based on the data of the register of managing organizations in Russia, presented on the portal of the State Corporation - the Fund for Assistance to Reforming the Housing and Communal Services (Housing and Utilities Reform).

- In the structure of managing organizations of the housing stock in the Ural Federal District, a significant share (about 62.5\%) falls on management companies; the rest of the organizations (about 37.5\%) are homeowners' associations, housing cooperatives and other specialized cooperatives.

- The housing and communal services market in the Ural Federal District among market operators is characterized by a low level of concentration (many operators with insignificant market shares).

\subsection{Trends in the development of the housing and communal services market in the Urals Federal District}

The key trends in the housing and communal services market in the Urals Federal District include:

- The popularity of non-cash payments in the housing and communal services sector is gaining momentum due to the convenience of making transactions - payment by QR code. According to a study by Sberbank - SberData, the shares of non-cash transactions in payments for housing and communal services in the regions of the Ural Federal District were: Yamalo-Nenets Autonomous Okrug (91.0\%), Khanty-Mansi Autonomous Okrug (91.0\%), Tyumen Region (85.0\%), Sverdlovsk region (79.0\%), Chelyabinsk region $77.0 \%$ ), Kurgan region $(71.0 \%)$. While on average in Russia, the share of non-cash transactions in payments for housing and communal services is $85.3 \%$.

- Among the qualitative trends in the development of the market is the creation and formation of institutions in housing and communal services, the activity of which is to develop effective solutions aimed at the development of housing and communal services. Such institutions and platforms include a single information resource - GIS Housing and Utilities, State Corporation - Fund for Assistance to Reforming Housing and Utilities (Housing and Utilities Fund), Comfortable Urban Environment and Housing and Utilities, Council for Professional Qualifications in Housing and Utilities (SPK Housing and Utilities), Smart City ", Association of Regional Operators of Major Repairs of Apartment Buildings (AROCR), Association of Housing and Utilities and the Urban Environment, Association" National Housing Congress ", Non-profit Partnership Housing and Utilities Control, School of Literate Consumers, DOM.RF - Financial Institute for the Development of the Housing Sector, FAU Glavgosexpertiza Russia ", FAU“ Roskapstroy ", FBU“ FCSIP ", FAU“FCS", etc.

- The tendency to increase the transparency of the housing and communal services market associated with the obligation to disclose information about the activities of the 
managing organization by publishing it on the official website intended for these purposes the Housing and Utilities Fund, as well as providing data on the housing stock in the GIS Housing and Communal Services. Besides, the Housing and Utilities Fund forms ratings of managing organizations, reflecting information on five blocks: the scale of activity, financial stability, efficiency, reputation, transparency.

One of the housing and communal services market's main problems is the low level of payment discipline (the ratio of payments made to the number of invoices for housing and communal services). Following the author's calculations based on Rosstat data, at the end of 2019, the level of payment discipline in the Urals Federal District regions was distributed as follows. The highest level of payment discipline is characteristic of the Kurgan Region (96.6\%), followed by the Khanty-Mansi Autonomous Okrug (96.0\%), then the Sverdlovsk Region (95.0\%). Further in descending order are the Tyumen Region (93.9\%), the Yamalo-Nenets Autonomous District (93.1\%), the Chelyabinsk Region (90.6\%). Simultaneously, the level of payment discipline in the Urals Federal District on average amounted to $93.9 \%$, while on average in Russia, this indicator was set at $95.4 \%$. According to experts, by the end of 2020, the increase in arrears on payments for housing and communal services, and a level of payment discipline decrease, will be facilitated by the amendments made to the Decree of the Government of the Russian Federation "On the provision of utilities to owners and users of premises in apartment buildings and residential buildings "in April 2020, providing for a moratorium on the accrual of penalties for unpaid utilities, the collection of penalties for late payment of utilities and contributions for overhaul. The moratorium is valid until the end of 2020, from 01.01.2021, penalties are charged on the entire amount of debt.

- The housing and communal services market, like many other areas, is subject to intensified digitalization processes. In particular, digital projects are being developed and IT products are being developed to make people's lives more comfortable. At present, according to experts, it is digitalization, the use of innovative, previously absent technologies to improve the quality of decisions made, including to increase the efficiency of previously performed automation, is a trend that determines the nearest prospects for the development of housing and communal services. Digitalization is aimed at solving a number of tasks, including: optimization of management processes - reducing losses, reducing indirect and overhead costs in tariffs; reducing the volume of accounts receivable and the resulting additional financial burden on housing and communal services enterprises; ensuring the transparency of the industry for public control and regulation; formation of a database of complete, reliable and up-to-date data, in particular, on the state of utility funds, the quality of services provided, consumption volumes and consumers of housing and communal services.

- Annual indexation of consumer tariffs for housing and communal services. Indexation of tariffs in 2020 was provided for by the Government's decree No. 2556-r dated October 29,2019 , on average in the country it was about $4.0 \%$. Each region has its own maximum allowable index. So, for example, for the Chelyabinsk, Sverdlovsk, Kurgan regions, the Khanty-Mansiysk Autonomous Okrug, it was 3.6\%, for the Tyumen region and the Yamalo-Nenets Autonomous Okrug - 4.0\%. These indices determined the maximum allowable growth in citizens' aggregate payment for utilities on average for the respective region.

- In 2020, the modernization of utility networks began, the depreciation of which is more than $60 \%$. The decision on the need to create a separate subprogram for the modernization of communal infrastructure, the wear of which exceeded $60 \%$, was made in 2019.The length of such dilapidated heat supply networks was estimated at $49,400 \mathrm{~km}$, water supply and sanitation $-328,100 \mathrm{~km}$. At the same time, in 2020, in the Urals Federal District, in addition to the already ongoing project for the construction of wastewater 
treatment facilities in the city of Verkhniye Sergi, Sverdlovsk Region, 8 projects for the modernization of communal infrastructure were accepted for consideration. In particular, the Sverdlovsk region - 2 projects for the construction of treatment facilities for domestic wastewater in Aramil and Verkhoturye, providing for co-financing of the Housing and Utilities Fund for 450.5 million rubles;

Chelyabinsk Region - 4 projects providing for the reconstruction of the right bank treatment facilities in Magnitogorsk, the heat supply system of the old part of Satka, as well as the modernization of the heat supply system in the Energetikov village of the Troitsk urban district with the co-financing of the Housing and Utilities Fund in 635 million rubles;

In Khanty-Mansi Autonomous Okrug 2 projects for the reconstruction of boiler houses in Kogalym and the Surgut region, in the amount of 209.8 million rubles. The total cost of these projects is 3.3 billion rubles, including almost 1.5 billion rubles. it is planned to attract from the funds of the Housing and Utilities Fund.

- One of the vectors of development of the housing and communal services market in Russia, including the Ural Federal District, is state programs and projects within the framework of reforming the housing and communal services, including the National Project "Housing and Urban Environment", covering four federal projects: "Mortgage", "Housing" , "Building a Comfortable Urban Environment" and "Ensuring a Sustainable Reduction of Unsuitable Housing Stock"; State program "Provision of affordable and comfortable housing and utilities for citizens of the Russian Federation"; Modernization of communal infrastructure in 2019-2025 (Federal Law of July 21, 2007 No. 185-FZ, Resolution of the Government of the Russian Federation of December 26, 2015 No. 1451 (as amended on February 11, 2019, No. 108)); Support for energy efficient overhaul in 2019-2025 (Federal Law dated July 21, 2007 No. 185-FZ, Government Decree No. 18 dated January 17, 2017, as amended on February 11, 2019 No. 108)), etc.

- In 2019, the Ministry of Construction of the Russian Federation approved the standards of "smart cities", which are planned to be introduced in cities with more than 100 thousand people within 5 years. As part of the digital transformation of housing and communal services, the priority area is the concept of "smart" housing and communal services with the introduction of modern technologies that make it possible to learn online all the necessary information about the technical condition of a house and its utilities, its problems and ways to solve them. Besides, one of the main areas of digital transformation included developing a mobile application that allows to quickly interact with the management organization and solve everyday problems remotely.

\subsection{Dynamics of the volume of the housing and communal services market in the Urals Federal District}

Let us consider the dynamics of the volume of the housing and communal services market in the Urals Federal District. According to the author's calculation, based on Rosstat data, the volume of the housing and communal services market in the Urals Federal District in 2020 amounted to 476.9 billion rubles, increasing by $5.1 \%$ relative to 2019 .

Throughout the analyzed period, there has been an increase in the volume of the housing and communal services market in the Urals Federal District in monetary terms, in current prices. The following factors were the drivers of the market volume growth every year: an increase in the number of serviced residential buildings and premises due to the annual growth of the housing stock; annual increase in consumer tariffs for housing and communal services; growth in investment in residential buildings and premises; the volume of social support provided to citizens to pay for housing and utilities in the form of subsidies paid; implementation of the National Project "Housing and Urban Environment", covering four federal projects: "Mortgage", "Housing", "Formation of a Comfortable Urban 
Environment" and "Ensuring a Sustainable Reduction of Unsuitable Housing Stock", as well as the implementation of the State Program "Provision of Affordable and comfortable housing and utilities for citizens of the Russian Federation "; support for mortgage lending. The dynamics of the volume of the housing and communal services market in the Urals Federal District in 2015-2020 is presented in Fig. 1.

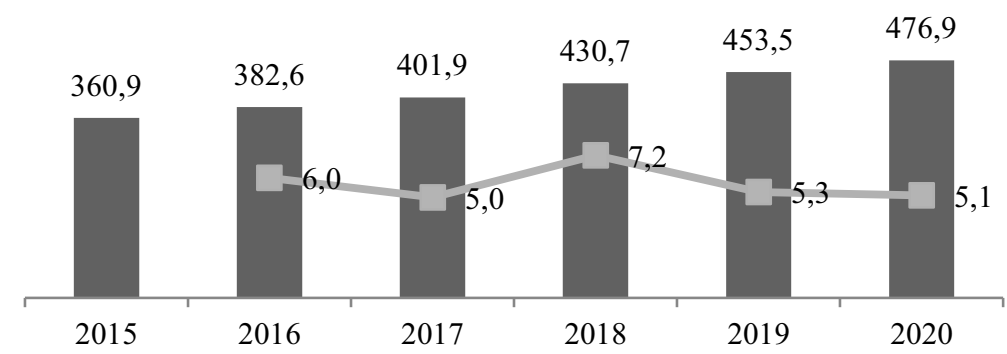

The volume of the HCK market in the Urals Federal District, billion rubles
Growth rate of market volume compared to last year, $\%$

Fig. 1. Dynamics of the volume of the housing and communal services market in the Urals Federal District, 2015-2020, billion rubles.

\subsection{The structure of the housing and communal services market in the Urals Federal District by region}

The structure of the provision of housing and communal services in the Ural Federal District in the context of regions and districts shows that the Sverdlovsk region occupies a leading position with a market share of $33.6 \%$, a slightly smaller share (second in the structure under consideration) - $32.3 \%$ belongs to the Chelyabinsk region, in third place Khanty-Mansiysk Autonomous Okrug - UGRA (share of 13.3\%). Further in descending order are the Tyumen region (share of 9.1\%), Yamalo-Nenets Autonomous Okrug (share of $8.3 \%$ ), and in last place is the Kurgan region (share of 3.0\%).

This distribution of shares in the provision of housing and communal services in the Ural Federal District by regions and districts indicates that two-thirds $(66.8 \%)$ of the housing stock is concentrated in two regions with the highest population density Sverdlovsk and Chelyabinsk regions, and their total share within the framework of the provision of housing and communal services is $65.9 \%$. At the same time, it is noteworthy that in some regions of the Urals Federal District (for example, when comparing the Tyumen Region and the Yamal-Nenets Autonomous Okrug), despite the smaller share of the housing stock of the Yamal-Nenets Autonomous Okrug in the structure of the housing stock $(4.3 \%)$, its the share in the provision of housing and communal services is almost two times higher (share of $8.3 \%$ ). While in the Tyumen region, the opposite situation is observed. This is due to the higher tariffs for housing and communal services established in the Yamalo-Nenets Autonomous Okrug and the lower population density compared with the Tyumen region. The structure of the provision of housing and communal services in the Ural Federal District and the structure of the Ural Federal District's housing stock in 2020 are presented in Fig. 2 and Fig. 3, respectively. 


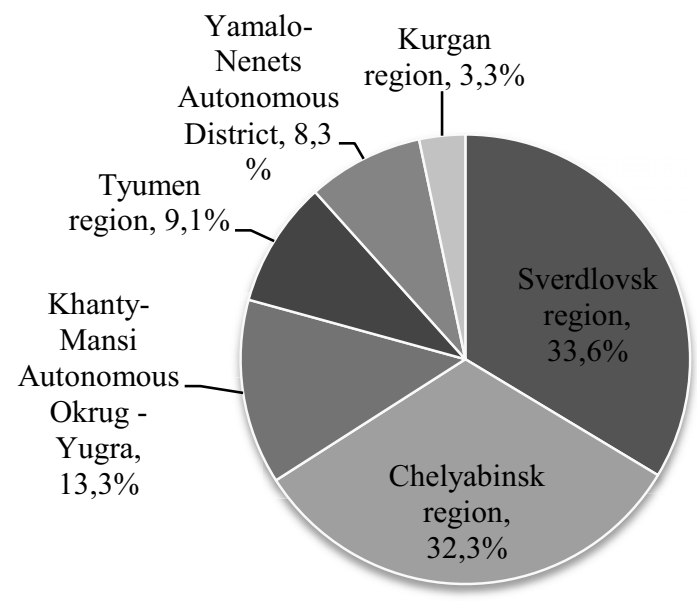

Fig. 2. The structure of the volume of housing and communal services in the Urals Federal District, $2020, \%$.

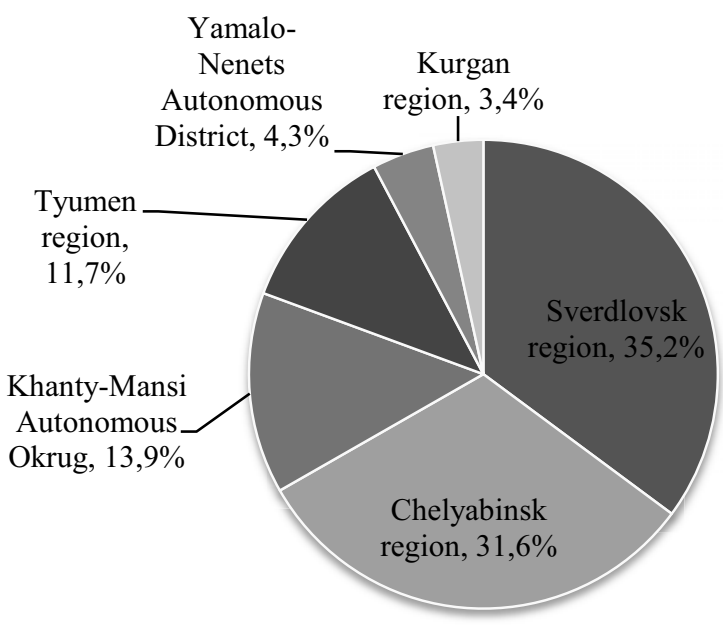

Fig. 3. The structure of the housing stock of the Urals Federal District by region, 2020, \%.

\section{Discussion and conclusion}

Firstly, the features of the housing and communal services market in the Ural Federal District have been investigated, indicating the absence of a properly formed institution of active and responsible owners of premises in apartment buildings with a certain level of responsibility. Moreover, the restraining factor for the development of the studied market in the Urals Federal District is the high physical and obsolescence of the communal infrastructure objects. Depreciation of heating and electrical networks in the Urals Federal District regions reaches $60.0 \%$, and of water supply and sewerage networks $-68.0-70.0 \%$, which is higher than the national average $-58.0 \%$.

Secondly, trends in the development of the Urals Federal District's housing and communal services market have been identified. The qualitative trends in the development of the market under study include the intensified processes of digitalization and digital 
transformation of housing and communal services, an increase in the transparency of the housing and communal services market associated with the obligation to disclose information about the activities of the managing organization on official Internet sites - the Fund for Housing and GIS Housing, the creation and formation of institutions in the field of housing and communal services, whose activity is to develop effective solutions aimed at the development of housing and communal services.

Thirdly, the dynamics of the volume of the housing and communal services market in the Urals Federal District in 2015-2020 is presented. Simultaneously, the dynamics of the studied market is predominantly linear, with an average annual growth rate of $5.7 \%$. So, in 2020 compared to 2015 , the market volume increased by almost a third $(+32.1 \%)$ and amounted to 476.9 billion rubles.

Fourthly, the drivers of the growth of the housing and communal services market in the Urals Federal District have been identified, including the implementation of the National Project "Housing and Urban Environment" and the State Program "Provision of affordable and comfortable housing and utilities for citizens of the Russian Federation"; the annual increase in the number of serviced residential buildings and premises, due to the increase in the housing stock; annual indexation of tariffs for housing and communal services; implementation of social support measures for citizens to pay for housing and utilities in the form of subsidies paid.

Fifthly, the structure of housing and communal services in the Urals Federal District by region has been investigated. The Sverdlovsk Region (33.6\% share) occupies a leading position with a slight advantage over the Chelyabinsk Region (share of 32.3\%). In general, both of these regions account for almost two-thirds of the Urals Federal District's housing and communal services market in value terms. This is primarily due to the high concentration of the housing stock in these regions (both regions account for $66.8 \%$ of the Ural Federal District's housing stock as a whole) and the high population density in them.

The results of this work help in further research to conduct a competitive analysis on the housing and communal services market in the Urals Federal District, determine the shares of the largest competitors in the studied market, estimate the volume of housing and communal services consumption per capita, as well as the saturation and estimated potential of the housing and communal services market in the Urals Federal District.

\section{References}

1. V. Barkhatov, E3S Web of Conferences 210, 15002 (2020) DOI:10.1051/e3sconf/202021015002

2. V. Barhatov, I. Belova, Proceedings of the 17th Eurasia Business and Economics Society Conference 5, 453-468 (2017) DOI: 10.1007/978-3-319-46319-3_28

3. V. Barkhatov, D. Benz, D. Pletnev, E3S Web of Conferences 210, 13013 (2020) DOI:10.1051/e3sconf/202021013013.

4. N. Kemaykin, M. Pavlenkov, Bulletin of the Tomsk State University 51, 21-34 (2020) DOI: $10.17223 / 19988648 / 51 / 2$

5. M. L'vova, T. Bakunova, T. Kol'tsova, Bulletin of the Voronezh State University of Engineering Technologies 4(78), 452-455 (2018) DOI: 10.20914/2310-1202-2018-4452-455

6. O. Nenakhova, North Caucasus Legal Vestnik 1(2), 87-91 DOI: 10.22394/2074-7306-2018-1-2-87-91

7. E. Nikolaeva, D Pletnev, Journal of Advanced Research in Law and Economics 6(4), 768-774 (2015) DOI:10.14505/jarle.v6.4(14).06 
8. D. Pletnev, O. Fink, O. Dyachenko, Eurasian Business Perspectives. Proceedings of the 25th Eurasia Business and Economics Society Conference 1, 127-137 (2020) DOI: 10.1007/978-3-030-35051-2_9

9. I. Plotnikova, I. Sorokina, Problems of Territory's Development 6(104), 52-68 (2019) DOI: 10.15838/ptd.2019.6.104.4

10. U. Shalbolova, Z. Chikibayeva, S. Yegemberdiyeva, Ye. Kim, E3S Web of Conferences 208(16), 04013 (2020). DOI: 10.1051/e3sconf/202020804013

11. H. Shtogryn, O. Sakal, I. Zapukhliak, I. Kinash, Journal Of Eastern European And Central Asian Research 6(1), 113-130 (2019). DOI: 10.15549/jeecar.v6i1.251

12. Yu. Sokolov, Issues of Risk Analysis 17(5), 10-25 (2020) DOI: 10.32686 / 1812-52202020-17-5-10-25

13. N. Taranukha, N. Zhuldybina, Bulletin of Kalashnikov ISTU 21(3), 100 (2018) DOI: 10.22213/2413-1172-2018-3-100-105 